\title{
Cytology of Oxalidaceae
}

\author{
P. M. Mathew \\ Botany Department, University College, Trivandrum, India \\ Received January 24, 1958
}

\section{Introduction}

The family Oxalidaceae consists of seven genera (Rendle 1952) and about 900 species, mostly pantropical, the greater number of which being distributed in the warmer parts of the world. Of the seven genera, Oxalis with about 800 species, which has one centre of distribution in South Africa and another in South America, forms the most conspicuous genus. The family is not well represented in India. Hooker (1875) lists only 15 species belonging to four genera as occurring in India. Gamble (1915) reports 9 species in three genera, Oxalis (1 species), Biophytum (6 species) and Averrhoa (2 species), in the former Presidency of Madras. Rama Rao (1914) has recorded 6 species in three genera as occurring in Travancore.

A considerable amount of work has been done in the past on the aytology of the family, especially on the important genus, Oxalis. As early cs 1927 Heitz listed the chromosome numbers of 26 species of Oxalis. Later investigators like Matsuura and Suto (1935), Kostoff et al (1935), Yamashita (1935), Wulff (1937) and Rutland (1941) have reported the cytology of about a dozen species of Oxalis. Quite recently Marks (1956) has studied the cytology of 24 species of Oxalis, of which 16 were South African and the rest South American. Krishnaswamy and Raman (1949) counted the chromosome number of one species of Averrhoa. The study reported here concerns five species of Oxalis namely $O$. pubescens, $O$. corniculata, $O$. pes-caprae, $O$. violacea and $O$. tetraphylla, two species of Averrhoa namely A. carambola and A. bilimbi and one species of Biophytum namely $B$. sensitivum.

\section{Materials and methods}

The materials for this study were collected from different places in South India. Oxalis pubescens, O. pes-caprae and O. tetraphylla were collected in September 1954 from Kodaikanal, where they are grown as garden plants. O. violacea was collected from Peermade. All the above mentioned species of Oxalis were found to grow well at higher altitudes. Other species like $O$. corniculata, Biophytum sensitivum, Averrhoa corambola and A. bilimbi were available locally in Trivandrum.

In all these materials the chromosome counts were made from pollen 
mother cells during meiosis. For this purpose flower buds were usually collected from plants growing in their natural condition and were fixed in Carnoy's fluid (absolute alcohol and glacial acetic acid in the ratio $3: 1$ ). Use of a trace of iron acetate in the fixative was found to be helpful in some cases in getting well stained preparations, but in the case of Oxalis this

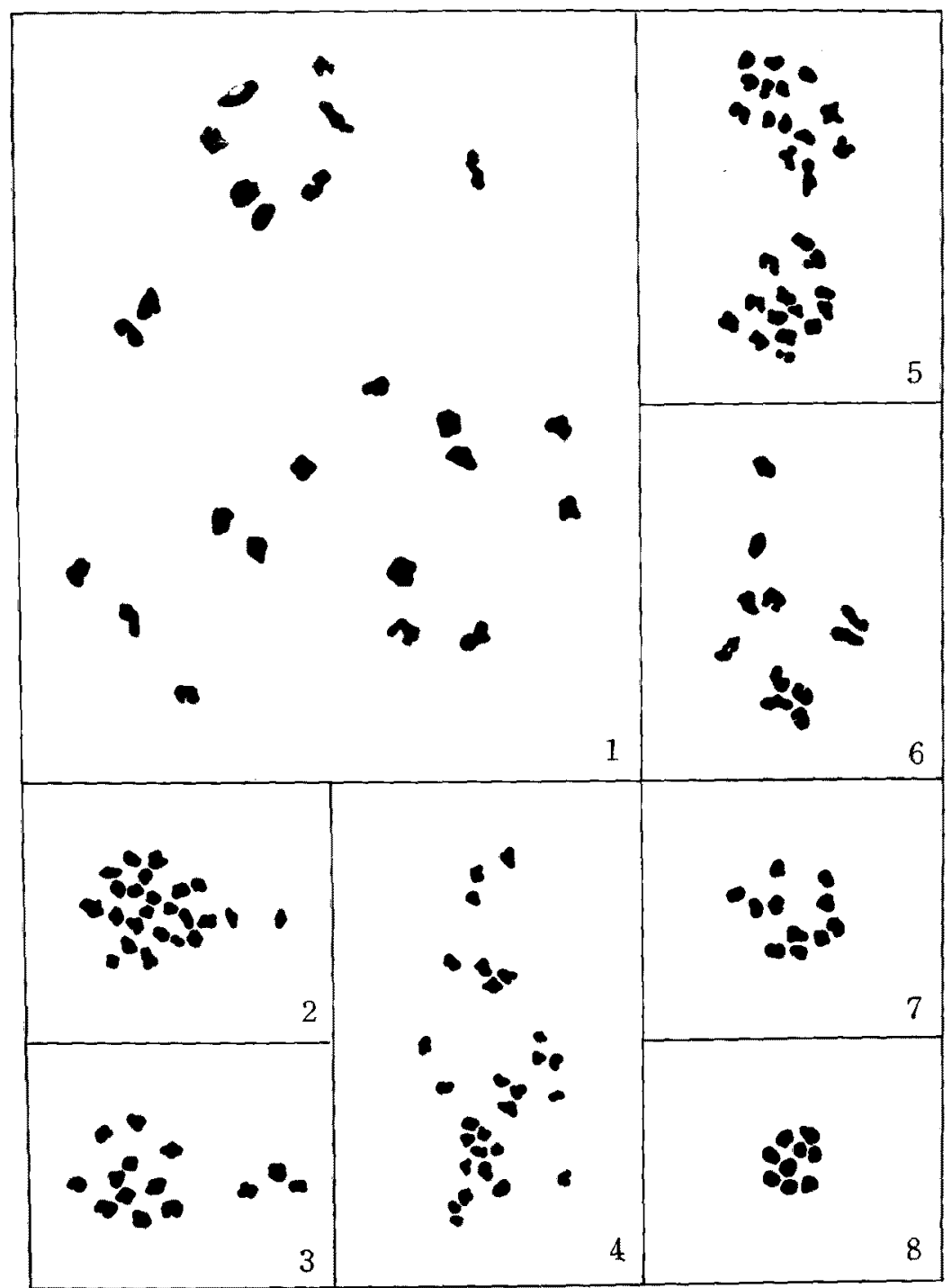

Text-figs. 1-8. Explanatory diagrams of Figs. 1-8 in Plate V. All Figs. $\times 1125.1$. Oxalis pubeseens, $n=24.2,0$. corniculata, $n=24.3,0$. pes-caprae, $n=14.4$, O. tetraphylla, $n=28$. 5, O. violacea, $n=14$. 6, Averrhoa bilimbi, $n=11$. 7, A. carambola, $n=11 . \quad 8$, Biophytum sensitioum, $n=9$.

did not produce any improvement on account of the tendency of the cytoplasm to absorb the stain. Fixed materials kept under low temperature in a refrigerator for at least a week produced sufficiently good results. Slides were prepared according to simple acetocarmine technique. Photomicrographs were 
taken usually from fresh smears. Explanatory diagrams were drawn on enlarged photographic prints taken on smooth white matt paper which were reduced to desired size in reproduction.

\section{Observations}

Oxalis Linn.

This is a tropical and subtropical genus consisting of over 800 species. In a monograph of the genus, Knuth (1930) describes them in 37 sections. Several species and varieties are grown as ornamental plants because of their brilliant yellow or purple flowers and beautiful foliage. The chromosome numbers of about 62 species have been reported by earlier investigators (listed elsewhere). Cytology of five species have been reported here, of which Oxalis corniculata is the only species indigenous to South India. All the others are introduced plants.

$O$. pubescens $\mathrm{H}$. B. and $\mathrm{K}$.

There is no previous cytological report on this species. During meiosis 24 bivalents were clearly observed in pollen mother cells at diakinesis (TextFig. 1 and P1. V, Fig. 1)

$O$. corniculata L.

Two chromosome numbers have been reported in this species by previous workers. While Rutland's report (1941) shows the number as $2 n=24$, Marks (1956) reported it as $2 n=48$. Result obtained from the present study agrees with that of Marks. During meiosis 24 bivalents were clearly counted from pollen mother cells at first metaphase (Text-Fig. 2 and P1. V, Fig. 2).

Bivalents at this stage showed a clumping tendency.

$O$. pes-caprae $\mathrm{L}$.

The chromosome number of this species has been reported by Marks (1956) as $2 n=28$. Present study also showed the same number. The number of bivalents observed during meiosis was 14 (Text-Fig. 3 and Pl. V, Fig. 3)

$O$. violacea Linn.

The cytology of this species is studied for the first time. The chromosome number was found to be the same as that in O. pes-caprae. This was found to be a comparatively difficult cytological material owing to the tendency of the cytoplasm to absorb and retain the stain. Meiosis was quite normal with regular anaphase separation which resulted in the clear disposition of 14 chromosomes each on either side of the cell. The metaphase of the second division with 14 chromosomes each in two groups is shown in Text-Fig. 5 and P1. V, Fig. 5.

O. tetraphylla Cav.

Of all the species of Oxalis studied during the present investigation this species showed the highest chromosome count. The number of bivalents 

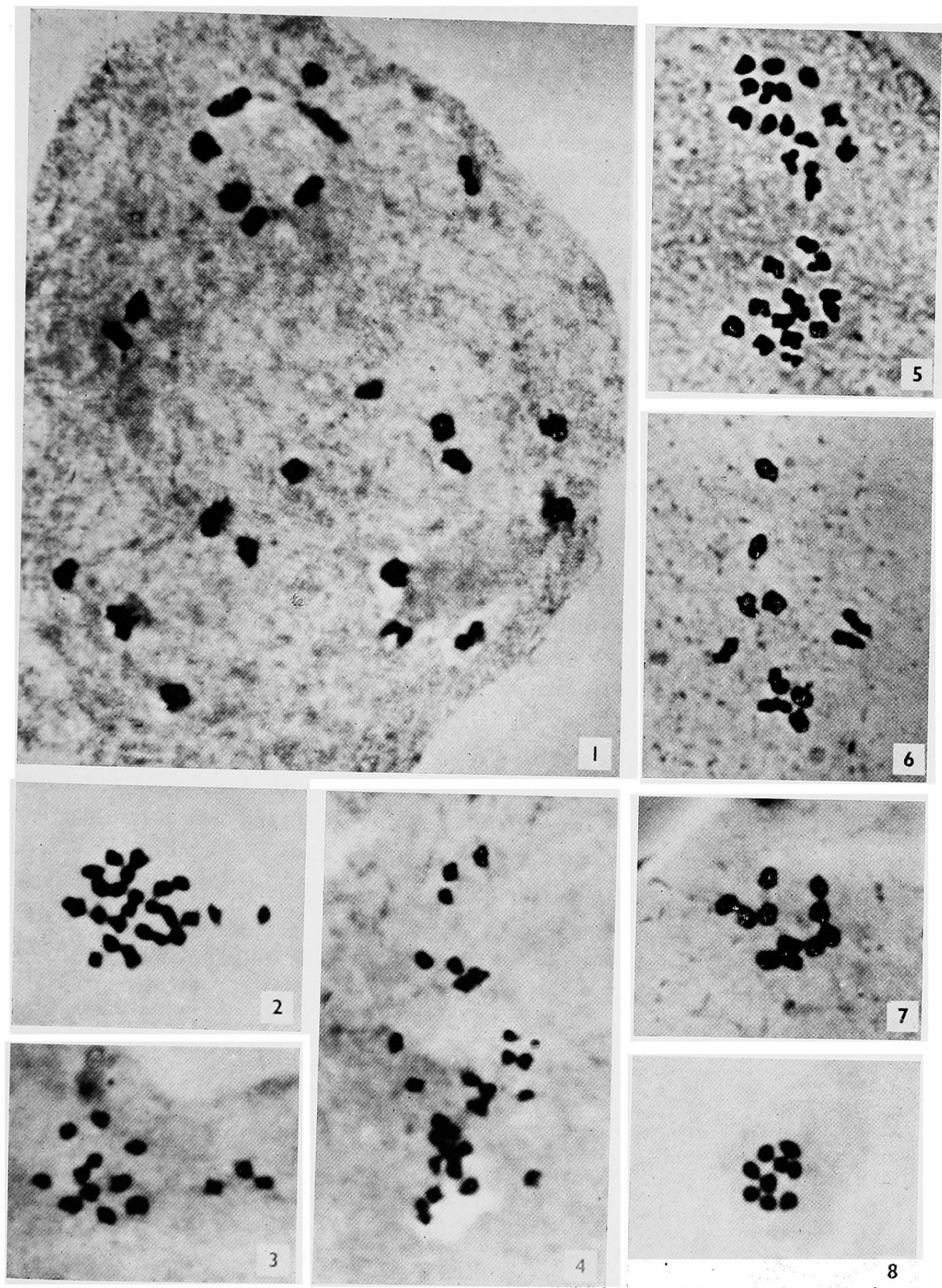

P. M. Mathew: Cytology of Oxalidaceae 
observed at metaphase I in pollen mother cells was clearly 28 (Text-Fig. 4 and P1. V, Fig. 4). Bivalents in this stage were very much condensed and they were smaller than those in the other species of Oxalis.

Biophytum De Cand.

This is a tropical genus with about 50 species. It is represented in India by 8 species (Hooker 1875), of which the cytology of only one is reported here. No previous cytological report on this genus is available.

B. sensitivum DC. Prodr.

Meiosis was studied from materials collected from two localities and the haploid chromosome number was found to be 9 in both. Bivalents at metaphase I are appreciably condensed and they take very good stain (TextFig. 8 and P1. V. Fig. 8). They were comparatively smaller in size.

Averrhoa Linn.

This is a tropical arborescent genus with only two species, A. bilimbi and A. carambola. These are cultivated for their fruit which tastes like goosberry.

\section{A. bilimbi Linn.}

There is no previous report on the chromosome number of this species. The number of bivalents counted from pollen mother cells at metaphase I was clearly 11 (Text-Fig. 6 and P1. V, Fig. 6). Meiosis was normal with regular anaphase separation.

A. carambola Linn.

The chromosome number in this species has been reported by Krishnaswamy and Raman (1949) as $2 n=24$. But the present study does not agree with their findings. The number of bivalents observed in several pollen mother cells was very clealy 11 (Text-Fig. 7 and P1. V, Fig. 7). The division was normal and four pollen grains of equal size were formed from each mother cell.

In the accompanying list is given the chromosome numbers so far known in the family Oxalidaceae.

Present study

\begin{tabular}{lllc}
\hline \multicolumn{1}{c}{ Species } & Locality & $\begin{array}{c}\text { Chromosome } \\
\text { number }\end{array}$ & Basic No. \\
\hline OXALIS & Kodaikanal & $n=24$ & 6 \\
O. pubescens & Trivandrum & $n=24$ & 6 \\
O. corniculata & Kodaikanal & $n=14$ & 7 \\
O. pes-caprae & Peermade & $n=14$ & 7 \\
O. violacea & Kodaikanal & $n=28$ & 7 \\
O. tetraphylla & Trivandrum & $n=9$ & 9 \\
BIOPHYTUM & & & \\
B. sensitivum & Trivandrum & $n=11$ & 11 \\
AVERRHOA & Trivandrum & $n=11$ & 11 \\
A. bilimbi & - & & \\
A. carambola & & & \\
\hline
\end{tabular}


Previous reports

\begin{tabular}{|c|c|c|c|c|}
\hline Species & $2 n$ number & Basic number & Author & \\
\hline Oxalis cernua & 35 & 7 & Yamashita & (1935) \\
\hline O. pes-caprae & 28 & 7 & Marks & (1956) \\
\hline O. dentata & 14 & 7 & Marks & (1956) \\
\hline O. bowiei & 28 & 7 & Marks & (1956) \\
\hline O. bowiei & 42 & 7 & Marks & (1956) \\
\hline o. purpurata & 28 & 7 & Heitz & (1927) \\
\hline o. caprina & 20 & 5 & Heitz & (1927) \\
\hline O. tragopoda & 14 & 7 & Marks & (1956) \\
\hline o. imbricata & 40 & 5 & Marks & (1956) \\
\hline O. incarnata & 14 & 7 & Marks & (1956) \\
\hline O. truncatula & 28 & 7 & Marks & (1956) \\
\hline o. truncatula & 42 & 7 & Heitz & (1927) \\
\hline O. smithiana & 14 & 7 & Heitz & (1927) \\
\hline o. purpurae & 42 & 7 & Marks & (1956) \\
\hline o. cathera & 14 & 7 & Marks & (1956) \\
\hline o. fabaefolia & 28 & 7 & Heitz & (1927) \\
\hline O. namaquana & 28 & 7 & Marks & (1956) \\
\hline O. massoniana & 14 & 7 & Marks & (1956) \\
\hline O. paradalis & 14 & 7 & Matks & (1956) \\
\hline o. hirta & 30 & 5 & Marks & (1956) \\
\hline O. hirta & 30 & 5 & Yamashita & (1935) \\
\hline O. tenuifolia & 28 & 7 & Heitz & (1927) \\
\hline O. ciliaris & 40 & 5 & Marks & (1956) \\
\hline o. cuneata & 12 & 6 & Marks & (1956) \\
\hline O. potyphylla & 30 & 5 & Heitz & (1927) \\
\hline o. versicolor & 14 & 7 & Heitz & $(1927)$ \\
\hline O. versicolor & 30 & 5 & Yamashita & (1935) \\
\hline O. versicolor & 30 & 5 & Marks & (1956) \\
\hline o. rhombifolia & ca. 80 & $?$ & Heitz & (1927) \\
\hline O. dispar & 12 & 6 & Marks & (1956) \\
\hline o. bupleurifolia & 10 & 5 & Heitz & (1927) \\
\hline o. bupleurifolia & 10 & 5 & Marks & (1956) \\
\hline O. ortgiesii & 14 & 7 & Heitz & (1927) \\
\hline O. ortgiesii & 14 & 7 & Marks & (1956) \\
\hline O. tuberosa & 14 & 7 & Heitz & (1927) \\
\hline O. valdiviensis & 18 & 9 & Warburg & (1938) \\
\hline O. valdiviensis & 18 & 9 & Marks & (1956) \\
\hline o. rosea & 14 & 7 & Heitz & (1927) \\
\hline O. rosea & 12 & 6 & Marks & (1956) \\
\hline o. corniculata & 24 & 6 & Rutland & (1941) \\
\hline o. corniculata & 48 & 6 & Marks & (1956) \\
\hline O. stricta & 24 & 6 & Wulff & (1937) \\
\hline O. chrysantha & 12 & 6 & Marks & $(1956)$ \\
\hline o. rubra & 42 & 7 & Heitz & (1927) \\
\hline O. articulata & 14 & 7 & Heitz & (1927) \\
\hline O. articulata & 14 & 7 & Marks & (1956) \\
\hline O. tuberosus & 63 & 7 & Kostoff & (1935) \\
\hline o. maritima & 28 & 7 & Marks & (1956) \\
\hline o. acetosella & 22 & 11 & Nakajima & (1936) \\
\hline
\end{tabular}




\begin{tabular}{lccll}
\hline Species & 2n number & Basic number & \multicolumn{2}{c}{ Author } \\
\hline O. acetosella & 22 & 11 & Marks & $(1956)$ \\
O. japonica & 35 & 7 & Matsuura & $(1935)$ \\
O. adenophylla & 28 & 7 & \& Suto & $(1927)$ \\
O. brasiliensis & 14 & 7 & Heitz & $(1927)$ \\
O. brasiliensis & 28 & 7 & Yamashita & $(1935)$ \\
O. brasiliensis & 28 & 7 & Marks & $(1956)$ \\
O. eriolepsis & 20 & 5 & Marks & $(1956)$ \\
O. drummondii & 14 & 7 & Heitz & $(1927)$ \\
O. grandiflora & 14 & 7 & Heitz & $(1927)$ \\
O. vespertilionsis & 14 & 7 & Heitz & $(1927)$ \\
O. violacea & 28 & 7 & Heitz & $(1927)$ \\
O. violacea & 28 & 7 & Yamashita & $(1935)$ \\
O. deppei & 14 & 7 & Heitz & $(1927)$ \\
O. deppei & 56 & 7 & Marks & $(1956)$ \\
O. lasiandra & 28 & 7 & Marks & $(1956)$ \\
Averrhoa carambola & 24 & $?$ & Krishnaswamy $(1949)$ \\
\hline
\end{tabular}

\section{Discussion}

Basic chromosome number and relationship of Oxalidaceae

From the chromosome determinations so far made on the family, as seen from the list above, it is obvious that Oxalis is a multibasic genus with fairly wide range of basic chromosome numbers. O. bupleurifolia is reported to have $2 n=10$ (Heitz 1927 and Marks 1956), and as this is the lowest diploid number so far known in the genus, 5 may be taken as the lowest basic chromosome number in Oxalis. Some of the other previously investigated species like $O$. eriolepsis Wedd. $(2 n=20)$, O. versicolor L. $(2 n=30), O$. ciliaris Jacq. $(2 n=40)$ etc. show different grades of polyploidy on the basic number 5 . However, no species of Oxalis, which can be brought under the group with 5 as basic number, has been observed during the present study of the genus. South African and South American species like $O$. cuneata Jacq., $O$. dispar Brown, $O$. rosea Jacq. and $O$. chrysantha Jacq., all showed $2 n=12$ (Marks 1956), and from these counts it is clear that 6 is the next higher basic number in Oxalis. Species like O. stricta L. with $2 n=24$ (Wulff 1937), and O. corniculata L. and O. pubescens H. B. and K., both with $n=24$, evidently are polyploid species on this number. Of the 62 species of Oxalis previously studied, the vast majority of them showed chromosome numbers in multiples of 7 , and in the present study also three species out of five, such as $O$. violacea $(n=14)$, O. pes-caprae $(n=14)$ and $O$. tetraphylla $(n=28)$, have chromosome numbers agreeing with the basic number 7 . This would mean that 7 is the predominant basic number in Oxalis, and on account of this Marks (1956) has even suggested that 7 is probably the archaic basic number for the genus, all others being 
derived from it by fragmentation or fusion of chromosomes during the course of evolution. Species like $O$. valdiviensis, possessing $2 n=18$ (Warburg, 1938 and Marks 1956), and $O$. acetosella having 22 somatic chromosomes (Nakajima 1936) show the presence in Oxalis of yet two more basic numbers, 9 and 11, The low frequency of these numbers together with complete absence of polyploid species of Oxalis on these indicates the probability of these being the last evolved numbers. Thus from the cytological data so far available it may be seen that $5,6,7,9$, and 11 are the existing basic chromosome numbers in the genus Oxalis, of which 7 is the most frequently occurring number.

Though Biophytum is a large genus containing about 50 species its cytology has not been studied before. The study made here on one species is therefore interesting in as much as it gives at least an idea about the basic chromosome number of the genus. The haploid number observed in $B$. sensitivum was $n=9$ and therefore 9 may be taken as the basic number of the genus. The scanty cytological knowledge of only one species is however, too insufficient to make a fuller discussion on the basic chromosome number of a large genus like this. But it is hoped that further study of a few more species of Biophytum which is in progress in this laboratory, would provide enough material for this.

Averrhoa is a small genus containing only two species, A. carambola and $A$. bilimbi. In both these the haploid number observed was $n=11$, and these findings make it possible to fix the basic number of the genus as 11. The previously reported number of $2 n=24$ in $A$. carambola (Krishnaswamy and Raman 1949) does not agree with this basic number.

Oxalidaceae has been treated by most systematists, including Hutchinson (1926), Rendle (1952), Lawrence (1951) etc., as a distinct family and they seem to be justified in doing so on morphological considerations, because the members of the Oxalidaceae are distinguished from those of the related families by the shortly monadelphous stamens, the five distinct styles, the single quinquilocular pistil and the usually palmately compound leaves. They agree that the family belongs in the Geraniales. But the earlier systematists like Bentham and Hooker (1862) grouped it as one of the four distinct tribes in the Geraniaceae, the four tribes being Geranieae, Oxalideae, Balsamineae and Tropaeoleae. Though it is a matter of considerable interest to view these taxonomic questions regarding the systematic position and affinities of the Oxalidaceae and the other related families of the Geraniales in the light of their cytology, the present study is not made with that end in view. A comprehensive work has been carried out by Warburg (1938) in this direction. In his endeavour to elucidate taxonomic relationships of the families of the Geraniales by means of investigations into their cytology, he has suggested that Geraniaceae, Oxalidaceae and Tropaeolaceae show close resemblance in cytological factors like chromosome number, chromosome 
size etc. He considers Limnanthaceae as the most primitive family in Geraniales and has traced out an evolutionary trend leading from Limnanthaceae through Balsamineae to the Geraniaceae, Oxalidaceae and Tropaeolaceae. On morphological characters Oxalidaceae is considered more closely related to Geraniaceae than to any of the other families in the Geraniales, and parallel to this there appears to have a cytological relationship too through the basic number 11 . In none of the other related families do we find this number (Darlington and Wylie 1955).

Polyploidy and speciation in Oxalidaceae

From the cytological data so far known on the family Oxalidaceae it is seen that a fairly wide range of basic numbers $(5,6,7,9$ and 11$)$ are prevalent in the genus Oxalis. Of these numbers, several grades of polyploidy (tetraploids, pentaploids, hexaploids and octoploids) occur on numbers 5,6 and 7 (Marks 1956, Heitz 1927 and Warburg 1938). Marks (1956), while studying the South African and South American species of Oxalis, has noticed that the degree of polyploidy is greater in the South African group, where "polyploidy is prevalent with little change in basic chromosome number". But in the South American group polyploids are less common and diploids are found to predominate. As all the different basic numbers reported for the genus are represented in this group it has been suggested that " changes of basic chromosome numbers have accompanied speciation in the South American group and seem to have resulted in great diversity and adaptability of types" (Marks 1956). All the five species of Oxalis examined during the present study are polyploids on the basic numbers 6 and 7 . Of these, $O$. pes-caprae, $O$. violacea, both with a haploid number 14 , are tetraploids, whereas $O$. pubescens $(n=24)$, O. corniculata $(n=24)$ and O. tetraphylla $(n=28)$ are octoploids. Thus from the known cytological data it is seen that, in addition to changes of basic chromosome numbers, polyploidy has been to a large extent responsible for the evolution of an unusually large number of species in Oxalis.

Biophytum is a large genus containing about 50 species, of which the cytology is known only of one species, B. sensitivum $(n=9)$. With this limitted knowledge it is not possible to make any discussion regarding the role of polyploidy towards speciation of the genus. Averrhoa is a small genus consisting of only two species, A. bilimbi and A. carambola, both diploids having $n=11$. Neither polyploidy nor change of basic chromosome number is seen to be operative in this genus, and this is suggested to be responsible for the relatively little evolution of species in Averrhoa.

\section{Summary}

1. Chromosome numbers of five species of Oxalis, one species of Biophytum and two of Averrhoa have been determined from pollen mother 
cells during meiosis. They are $n=24$ in Oxalis pubescens and O. corniculata, $n=14$ in $O$. pes-caprae and $O$. violacea, $n=28$ in $O$. tetraphylla, $n=9$ in Biophytum sensitivum, and $n=11$ in Averrhoa bilimbi and A. carambola.

2. All the species of Oxalis studied were polyploids on the basic numbers 6 and 7 . From a review of all the cytological data on the genus it is seen that 5,6,7,9 and 11 are the basic chromosome numbers in Oxalis, 7 being the most frequently occurring number. Biophytum and Averrhoa have 9 and 11 respectively as their basic numbers.

3. Affinities of the family are briefly considered in the light of cytological findings. Oxalidaceae is suggested to be more closely related to Geraniaceae.

4. Polyploidy, side by side with considerable change of basic chromosome numbers, is suggested to have been responsible for the evolution of a large number of species in Oxalis, while polyploidy and change of basic numbers are absent in Averrhoa.

\section{Acknowledgement}

This work was carried out under the supervision of Professor A. Abraham, Head of the Department of Botany, University College, Trivandrum. I wish to express my deep indebtedness to him for valuable guidance and encouragements. I am thankful to the Ministry of Education, Government of India for the award of a Junior Research Scholarship. My thanks are also due to the University of Kerala for excellent research facilities.

\section{References}

Bentham, G. and Hooker, J. D. 1862. Genera Plantarum.

Darlington, C. D. and Wylie, A. P. 1955. Chromosome atlas of flowering plants, George Allen and Unwin Ltd., London.

Gamble, J. S. 1915. Flora of the presidency of Madras. Part I. 132-33.

Heitz, E. 1927. Uber multiple und aberrante Chromosomzahlen, Abh. Geb. Naturw. 21: $47-58$.

Hooker, J. D. 1875. Flora of British India Vol. I., L. Reeve and Co., Ashford, Kent.

Hutchinson, J. 1926. The families of flowering plants, I. Dicotyledons, Macmillan and Co., London.

Knuth, R. 1930. Oxalidaceae. Das Pflanzenreich, Berlin.

Kostoff, D., Dogadkina, N. and Tichonov, A. 1935. Chromosome numbers in certain angiosperm Plants, C. R. Acad. Sci., U. R. S. S. 3: 401.

Krishnaswamy, N. and Raman, V. S. 1949. Curr. Sci., 18: 376.

Lawrence, G. H. M. 1951. Taxonomy of vascular plants, Macmillan and Co., New York.

Marks, G. E. 1956. Chromosome numbers in the genus Oxalis. New Phytol., 55: 120-29.

Matsuura, H. and Suto, T. 1935. Contributions to the idiogram study in Phanerogamous plants I. J. Fac. Sci. Hokkaido Univ. 5: 33.

Nakajima, G. 1936. Chromosome numbers in some crops and wild angiosperms. Jap. J. Genet. 12: 211.

Rama Rao, M. 1914. Flowering plants of Travancore, Govt. Press, Trivandrum. 
Rendle, A. B. 1952. The classification of flowering plants, Vol. II. (Revised edn.), Cambridge University Press.

Rutland, J. P. 1941. The merton catalogue. New Phytol. 40: 210.

Warburg, E. F. 1938. Taxonomy and relationships in the Geraniales in the light of their cytology. New Phytol. 37: 130-59 and $189-210$.

Wulff, H. D. 1937. Chromosomen studien an der schleswigholsteinischen Agiospermen, Flora I. Ber. dtsch. bot. Ges. 55: 262.

Yamashita, K. 1935. Zytologische Studien an Oxalis I. Jap. J. Genet. 11: 36.

\section{Explanation of Plate V}

All photomicrographs at a magnification of $\times 1935$.

Fig. 1. Meiosis in Oxalis pubescens H. B. and K. showing 24 bivalents in pollen mother cells. 2. Meiosis in $O$. corniculata $\mathrm{L}$. with 24 bivalents in pollen mother cells at metaphase I. 3. Meiosis in O. pes-caprae L. showing 14 bivalents in pollen mother cells. 4. Meiosis in $O$. tetraphylla Cav. showing 28 bivalents in pollen mother cells at metaphase I. 5 . Meiosis in $O$. violacea Linn. with 14 chromosomes each in two groups at the metaphase of the second division. 6. Meiosis in Averrhoa bilimbi Linn. showing 11 bivalents in pollen mother cells at first metaphase. 7. Meiosis in $A$. carambola Linn. with 11 bivalents in pollen mother cells. 8. First meiotic metaphase of Biophytum sensitivum DC. Prodr showing $n=9$. 